\title{
The Unavoidable Palm Oil Can Be Sustainable
}

\author{
G.H. Yue ${ }^{1,2,3, *}$, B.Q. Ye ${ }^{1}$ and A. Suwanto ${ }^{4}$ \\ 1 Temasek Life Sciences Laboratory, 1 Research Link, National University of Singapore, \\ Singapore 117604 \\ 2 School of Biological Sciences, Nanyang Technological University, 6 Nanyang Drive, Singa- \\ pore 637551 \\ ${ }^{3}$ Department of Biological Sciences, National University of Singapore, Singapore 117543 \\ ${ }^{4}$ Department of Biology, Faculty of Science and Mathematics, IPB University, Bogor, 16680 \\ West Java, Indonesia
}

\begin{abstract}
The oil palm is the most productive oil-producing crop. To yield the same volume of oil that is from one hectare of palm, eight hectares of soybean are needed. Palm oil is used an ingredient in over $50 \%$ of packaged supermarket products and also as biofuels. The palm oil sector provides over 4.5 million jobs for on-farm laborers in developing countries. However, palm oil is often blamed for deforestation and loss of biodiversity. We argue that palm oil sustainability is not only about the environment and biodiversity but also about people and their prosperity. Palm oil sustainability can be achieved with joint efforts from palm oil players including the smallholders, plantation companies, governments, certification agencies, consumers and researchers.
\end{abstract}

Keywords: Palm, ecology, livelihood, sustainability

\section{INTRODUCTION}

Oil palm is the most productive oil producing plant on the earth. Palm oil has been used as edible oil in African as far back as 5,000 years. Plantation of oil palm for oil has started since 1800s (Corley and Tinker, 2015; EPOA, 2019; Soh, et al., 2018). Due to the ever increasing requirement for edible oil and biofuels, currently there are over 30 countries producing palm oil, among which, Indo- nesia and Malaysia are the major palm oil producers, contributing $85 \%$ of the world palm oil production (Santosa, et al., 2020; ST, 2019). Oil palm plantation has increased livelihoods for many smallholders in developing countries (Begum, et al., 2018; Rist, et al., 2010). However, oil palm plantation has been blamed for deforestation, environmental destruction and loss of biodiversity (Fitzherbert, et al., 2008; Ordway, et al., 2019). Some developed countries proposed to ban the use

${ }^{*}$ Corresponding author:

Email: genhua@tll.org.sg 
of palm oil for the production of biofuels (Zaki and Rahim, 2019). In this paper, we systematically present the facts of palm oil and the challenges in oil palm sector to convince people that palm oil is unavoidable. In addition, we propose a roadmap to reach sustainable palm oil production.

\section{RESULTS AND DISCUSSION}

\section{Facts about palm oil}

Oil palm (Elaeis guineensis jacq) tree, originating in West Africa, is a perennial crop that bears fruits containing palm oil and palm kernel oil (Corley and Tinker, 2015) (Figure 1). Once planted, the palm trees can be used for harvesting fruits for 25 to 30 years (Corley and Tinker, 2015). In West Africa, the attempts to establish commercial-scale plantations in the early 1800s were not successful, while the commercial plantation of oil palm in Ma- laysia and Indonesia expanded rapidly after the first plantation in 1917 (Corley and Tinker, 2015). In the past 100 years, due to the selective breeding of oil palm trees for high oil yield, introducing an African weevil for pollination, hybridization between different forms of oil palm and the improvement of field management, the average crude palm oil (CPO) yield increased from two tons/ha/yr to 3.8 ton/ ha/yr (Corley and Tinker, 2015; Soh, et al., 2018). According to the European Palm Oil Alliance (EPOA, 2019), in 2015, among major oilseed crops, oil palm took up the smallest percentage $(6.6 \%)$ of cultivated land for oils and fats globally, but generated the largest percentage $(38.7 \%)$ of total oil production (Figure 1). Global CPO production increased from 15.2 million tons in 1995 to 62.5 million tons in 2017. Palm oil is mainly produced in Indonesia (53.0\%), Malaysia (32.0\%)

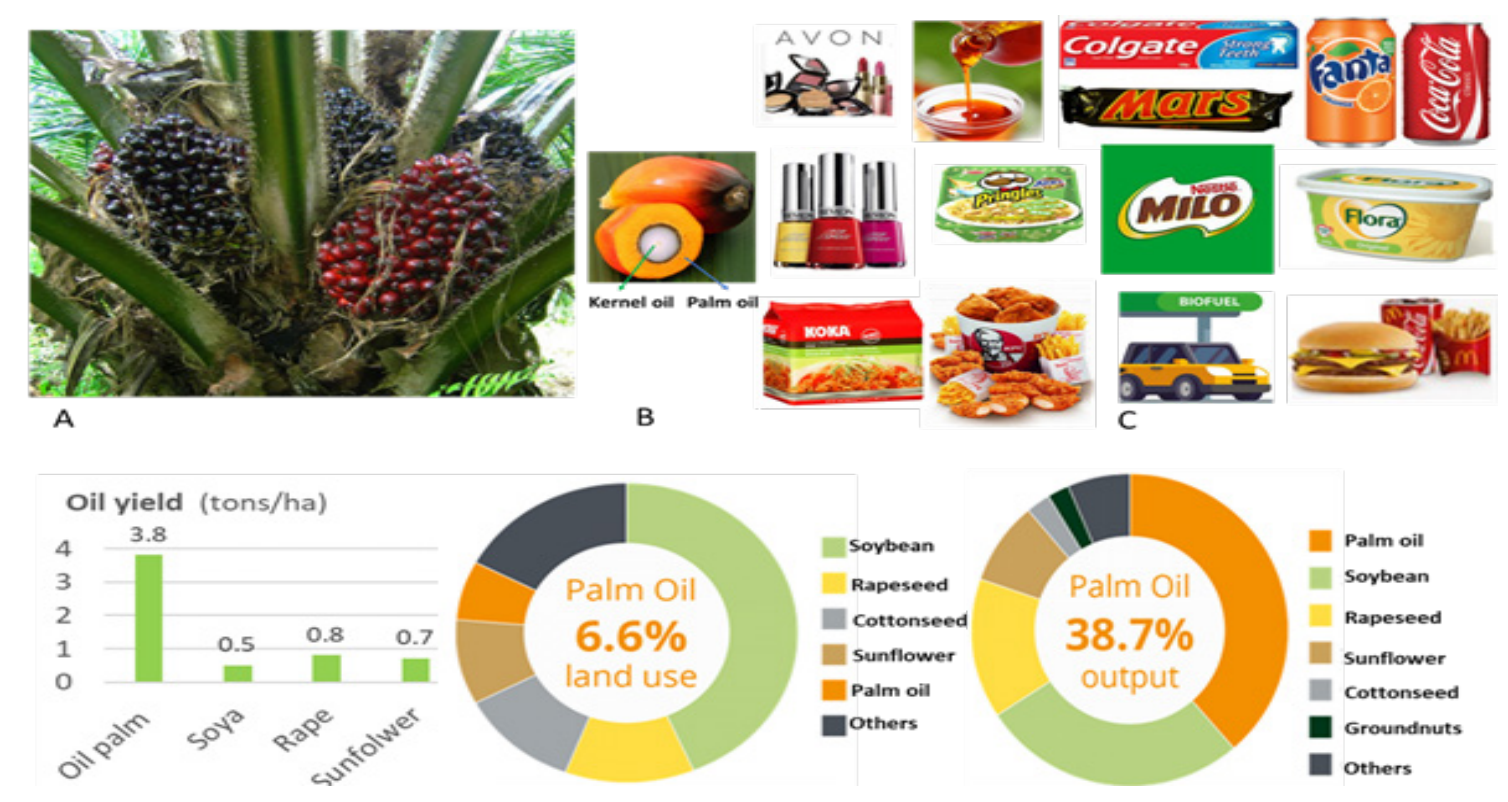

Figure 1. Facts about palm oil

A: A palm tree bearing fruits containing $20-35 \%$ oil. B: Oil palm fruits contain two types of oil: palm oil from the mesocarp and kernel oil from seeds. C: Palm oils have been used in over $50 \%$ of packaged products in supermarkets and are also being used as biofuel. D: Oil palm tree is the most productive among all oil producing crops. On a one-hectare land, oil palm produces $7.60,4.75$ and 5.43 times more oil than soybean, rapeseed and sunflower, respectively. E and F: In 2015, among major oilseed crops, oil palm takes up the smallest percentage $(\sim 6.6 \%)$ of all the cultivated land for oils and fats globally, but produces the largest percentage $(\sim 38.7 \%)$ of total output. 
and over 28 other developing countries (15.0\%) (Gatti, et al., 2019; Naylor, et al., 2019). The oil palm sector contributes significantly to the economy of Indonesia, Malaysia and other developing countries producing palm oil, and improves the livelihoods of over 4.5 million smallholders in developing countries (Begum, et al., 2018; Rist, et al., 2010). Palm oil is resistant to oxidation, rich in vitamin $\mathrm{E}$ tocotrienols and tocopherols, cholesterol-free, transfat-free, GMO-free and stable at high temperature (Lai, et al., 2015). It also has a long shelf life and balanced fatty acid content (Mancini, et al., 2015; Shimizu and Desrochers, 2012). Palm oil is the most commonly consumed vegetable oil (EPOA, 2019). Palm oil accounts for over one-third of global consumption of vegetable oil and is present in half of packaged supermarket products, ranging from toothpaste to snacks and cosmetics (Lai, et al., 2015). It is also being used as biodiesel (Corley and Tinker, 2015). It is expected that the demand for palm oil will continue rising due to the increase of the human population size on the earth (Wilman, 2019). Therefore, it is safe to conclude that palm oil is unavoidable and irreplaceable.

\section{Challenges of the palm oil sector}

The oil palm sector is facing challenges. It is often blamed for causing the loss of forests (Ordway, et al., 2019) and biodiversity (Fitzherbert, et al., 2008) (Figure 2), as well as abuses of human rights (McPhail and Maimunah, 2012), which turns the popular opinion against palm oil in some developed countries (Fitzherbert, et al., 2008; Gatti, et al., 2019). However, the major palm oil-producing countries, Malaysia and Indonesia, still maintain a higher percentage (> 43\%) of forests in total land area as compared to developed countries (<35\%) and the world average (30\%) (Perbet, et al., 2019; Ya- mamoto, et al., 2019). Therefore, developed countries should be fair to developing countries and allow them to use some parts of their forests for planting oil palms to alleviate poverty and improve their livelihoods. Furthermore, both Indonesia's and Malaysia's governments ordered a halt to the use of forests for new palm oil plantation in 2019 (ST, 2018; 2019). It is anticipated that other palm oil producing countries will follow suite.

It is true that during the take-off of the palm oil sector, some forest areas were cleared for oil palm plantation (Koh and Wilcove, 2008) to provide people with shelter, food, warmth and education for their kids (Ordway, et al., 2019). In the past 10 years, both governments and big companies involved in oil palm plantation have tried very hard to minimize the use of forests for oil palm plantation (Higgins and Richards, 2019). Although oil palm plantation is still one of the key causes for deforestation in some countries, its impact on deforestation has been reduced significantly as Indonesia's and Malaysia's governments have taken measures in reducing the use of forests for palm plantation (Naylor, et al., 2019; Santosa, et al., 2020; ST, 2018; 2019). African and south American countries, which are developing oil palm plantations, are also taking measures to minimize the use of forests for palm plantation and to protect the environment (Meijaard, et al., 2018). The current most significant oil palm expansion, which is associated with deforestation, is being driven by independent smallholders who are not part of palm oil companies (Austin, et al., 2019). It is anticipated that smallholders will manage $50-60 \%$ of total oil palm plantation area by 2030 (Austin, et al., 2019). Thus, engaging the smallholders could be critical for the sustainability of palm oil. 


\section{Proposing to boycott palm oil is not the answer to its sustainability.}

Palm oil sustainability is an issue about not only the environment and ecology but also people and their livelihoods. Proposing to ban palm oil is not the answer to its sustainability. Such a ban would have only negative effects on both people and the environment. Most palm oil companies have complied with their commitments and many are actually pioneering in sustainability commitments. Prohibiting palm oil will only discourage players who have worked for the sustainability of the sector for many years. Producing the equal amount of another vegetable oil needs much more land (EPOA, 2019). For example, to yield the same volume of oil that is from one hectare of palm, it takes up 4.75 hectares of rapeseeds, 5.43 hectares of sunflowers or 7.60 hectares of soybeans. If all palm plantation is switched to soybean culture, it would need around eight times as much land. On the Earth, we do not have such big land to open up for plantation of another oil crop. No other oil-producing plants can replace the oil palm, and thus palm oil is unavoidable. Eliminating support for the companies trying to make palm plantation sustainable would give competitive advantages to the ones which care only about profits. Supporting the companies and smallholders who do not use forests for palm production will help make the sector more sustainable. If palm oil is banned from production of biofuels, millions of smallholders will lose their livelihoods, and another oil crop would cause much more deforestation and in turn result in more environmental and ecological problems.
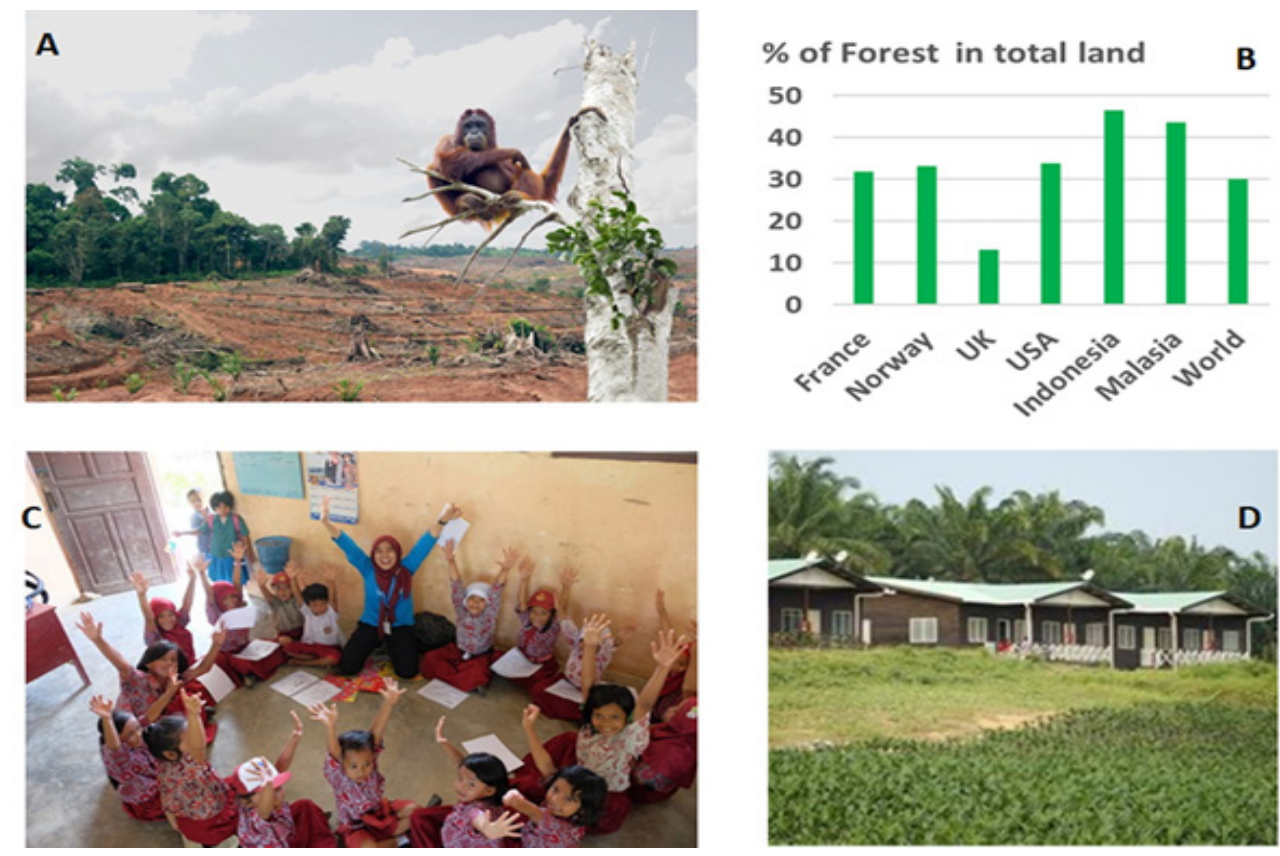

Figure 2. Effects of oil palm on environment and humans

A and B: Oil palm is often blamed for deforestation and loss of biodiversity (A), while the fact is that in the two major countries (Indonesia and Malaysia) producing $85 \%$ of the total palm oil on the Earth (B), there are still over $45 \%$ of their land covered with forest, which is much higher than that $(<35 \%)$ in the developed countries and the world average $(30 \%)$. C and D: The oil plantation contributes significantly to the livelihood of smallholders and makes it possible for them to have their housing (D) and have their kids educated (C). 


\section{Proposing to boycott palm oil is not the answer to its sustainability}

Palm oil sustainability is an issue about not only the environment and ecology but also people and their livelihoods. Proposing to ban palm oil is not the answer to its sustainability. Such a ban would have only negative effects on both people and the environment. Most palm oil companies have complied with their commitments and many are actually pioneering in sustainability commitments. Prohibiting palm oil will only discourage players who have worked for the sustainability of the sector for many years.

Producing the equal amount of another vegetable oil needs much more land (EPOA, 2019). For example, to yield the same volume of oil that is from one hectare of palm, it takes up 4.75 hectares of rapeseeds, 5.43 hectares of sunflowers or 7.60 hectares of soybeans. If all palm plantation is switched to soybean culture, it would need around eight times as much land. On the Earth, we do not have such big land to open up for plantation of another oil crop. No other oil-producing plants can replace the oil palm, and thus palm oil is unavoidable. Eliminating support for the companies trying to make palm plantation sustainable would give competitive advantages to the ones which care only about profits. Supporting the companies and smallholders who do not use forests for palm production will help make the sector more sustainable. If palm oil is banned from production of biofuels, millions of smallholders will lose their livelihoods, and another oil crop would cause much more deforestation and in turn result in more environmental and ecological problems.

\section{Roadmaps to sustainable palm oil}

It is true that the palm oil sector is now at a crossroads (Carrasco, et al., 2014). We need to find ways to minimize its neg- ative effects on environment and ecology, and ensure its sustainability and profitability (Carrasco, et al., 2014). We believe that increased smallholders' awareness on the importance of palm oil sustainability, certification of palm oil from sustainable sources (Paoli, et al., 2010), the involvement of governments (ST, 2018; 2019), increasing yield (Woittiez, et al., 2017) and more holistic field management (Goh, et al., 1999) will improve the palm oil sustainability and profitability.

Smallholders that are not linked to any particular company or mill, have not received any training on the sustainability of palm oil. What they care about is their livelihoods. To effectively mitigate the threats of oil palm to biodiversity and forests, researchers, including ecologists and conservationists, need to supply solid evidence to educate these independent smallholders and let them understand the negative effects of using forests for oil palm plantation on biodiversity and environment. It is also essential to educate and persuade consumers to continue demanding both transparency in land-use decisions by governments and greater environmental accountability from oil palm producers (Koh and Wilcove, 2009; Koh and Lee, 2012). Prohibiting the further use of primary or secondary forests for oil palm plantation is the way to safeguard tropical biodiversity. To monitor whether new oil palm plantations use primary or secondary forests, ecologists could use novel monitoring technologies, including remote sensing technologies (Liaghat and Balasundram, 2010), geoinformation technologies (Kamiran and Sarker, 2014), blockchain technology (Hirbli, 2018), and internet of things (IoT) technologies (Navulur and Prasad, 2017).

Certification is a good way to ensure palm oil sustainability (Paoli, et al., 2010) because it gives a quick and transparent way for consumers to know which prod- 
ucts are more responsibly produced products and an incentive for companies to switch to more sustainable suppliers and production methods. There are at least seven different schemes of certifications for palm oil, including RSPO (Roundtable on Sustainable Palm Oil), ISCC (International Sustainability and Carbon Certification), MSPO (Malaysian Sustainable Palm Oil), SAN (Sustainable Agriculture Network), RSB (Roundtable on Sustainable Biofuels), HCS (High Carbon Stock) and ISPO (Indonesian Sustainable Palm Oil standard). Some of the certification systems (e.g. ISPO) have tailor-made modules for specific needs of different market players, which is an important measure to involve the smallholders. In comparison with other oil crops, palm oil has the most sustainability certification schemes. Currently, most of the big companies are certified for palm sustainability, while only $1 \%$ of independent smallholders' farms are certified as sustainable (Gatti, et al., 2019). It is noteworthy that some certifications are very expensive for smallholders. A recent study (Hutabarat, et al., 2018) showed that the cost of the certification was about 86 euro per hectare, which created an average of $8 \%$ loss of net income per hectare per smallholder, compared to the situation prior to certification. To encourage independent smallholders to strive and apply for certification, the economic benefit to certified smallholders should be increased.

Governments can play more roles in palm oil sustainability. Smallholders lack the capacity to meet the certification standards, and thus their inclusion for sustainability is limited. Involvement of smallholders in sustainability is in the interest of governments, plantation companies and consumers. First, governments could provide most of the sustainability items required for certification of sustainability, thus lowering costs for smallholders.
They could provide trainings on sustainability, and novel and environment-friendly farming technologies. The governments can synchronize agencies involved in the regulations of palm oil in reducing costs for smallholders and increasing certifications. Second, the governments can allocate a portion of some funds (e.g. the Indonesian Crude Palm Oil (CPO) Supporting Fund) to help smallholders. They can be used to increase their productivity, such as paying for replanting with high-yield seedlings, thus reduce the land area to produce the same amount of palm oil. These funds would also enable smallholders to pursue certification and more sustainable production. Third, support for initiatives, which involve large oil palm companies working with smallholders to reduce deforestation and increase productivity, could definitely increase the palm oil sustainability.

Improving oil yield using novel technologies is an important solution to palm oil sustainability. To stop the deforestation, which is needed to enlarge oil palm plantation, it is essential to improve oil yield of the existing plantation to meet increasing demand (De Pinto, et al., 2017). Palm oil companies have been investing heavily in technologies for breeding, field management and improving efficiency in mills to boost palm oil sustainability. Sharing novel knowledge and technologies is critical for improving yield/hectare. The problem is that many new technologies are developed by individual companies and not shared with the whole sector. There is a big difference in oil yield between the big companies ( 5 tons/ha/yr) and the smallholders (< 3 tons/ha/yr) (Soh, et al., 2018). This is mainly because of the lack of funds for replanting with high-yield seeds, and technologies of proper fertilization and land management.

The lack of funds and technologies causes the lower productivity of small- 
holders and keeps their incomes low. In turn, in order to increase their income, they tend to expand their palm oil plantations into forests. Companies have been employing on technologies that work throughout the production chain, from planting materials to finished products. The improved seeds are more climate-resilient and potentially tolerant to certain diseases. Therefore, to close the yield gap across the whole sector, it is essential to share knowledge and technologies. Furthermore, novel molecular breeding technologies, including marker-assisted selection and genomic selection (Heffner, et al., 2009), are proven to be effective in accelerating genetic improvement of rice and maize. Fortunately, in oil palm, many genomic resources and tools, including the whole genome sequences (Jin, et al., 2016; Singh, et al., 2013a), the Shell gene (Singh, et al., 2013b), the fruit colour gene (Singh, et al., 2014) the gene responsible for mantled flowering in tissue-cultured palms (Ong-Abdullah, et al., 2015), genome wide SNPs and high density linkage maps (Bai, et al., 2018; Kwong, et al., 2016; Lee, et al., 2015; Pootakham, et al., 2015; Ting, et al., 2014) have been developed to accelerate the genetic improvement of the economically important traits, including oil yield, resistance to diseases, oil quality and tree height. These resources have been used in mapping QTL (Bai, et al., 2017; Billotte, et al., 2010; Lee, et al., 2017; Pootakham, et al., 2015; Singh, et al., 2009) or genome wide association study (GWAS) (Teh, et al., 2016) for economically important traits. All these studies showed the great potential in using novel technologies to improve the economically important traits in oil palm (Kwong, et al., 2017). New development of novel technologies, including genome editing (Wayne, et al., 2019), has opened a new way to speed up the improvement of oil yield and quality. The current world- wide average palm oil yield is only 3.8 tones/ha, while the theoretical maximum yield could reach 18.2 tones/ha (Corley and Tinker, 2015). Therefore, there is substantial space to improve per unit land oil yield. We anticipate that these novel technologies will substantially improve oil yield, thus minimizing the amount of land required for palm plantation and increasing the profit for smallholders.

Besides improving technologies, recent research (Padfield, et al., 2019) found that the researches on the effects of the expansion of oil palm agriculture across the tropics on environmental, social and economic impacts are not enough, and might not be not adequate. It is essential to improve regional academic leadership and coordination, greater engagement with private and public stakeholders of Southeast Asia, Africa, and Central and South America, and enhanced collaborative efforts with researchers in the major consuming countries of India and China. Therefore, we urge for closer collaboration between governments, palm companies and research institutions to speed up the development and implementation of new technologies. It is possible that the technologies being developed will be fast enough to curb the rate of deforestation. The big companies should show the smallholders that their livelihoods can be improved with the adoption of new technologies and advanced eco-friendly production approaches. This will equip them with a better capacity to reduce the risks of environmental hazards such as forest fires while promoting a cleaner and sustainable future for the palm oil sector. Only with a more efficient use of land and increased awareness of the importance of palm oil sustainability and wealth of the smallholders will they be better able to devote more resources to the protection of the forests. 


\section{CONCLUSIONS}

Oil palm is the most productive oil producing crop on the earth and is replaceable. The plantation of the oil palm contributes significantly to improve the livelihoods of farmers and also to world food security. However, the oil palm plantation in forests could cause loss of biodiversity and rise environmental issues. Proposing to boycott palm oil for the production of biofuels is not the way to reach ecological sustainability. It will cause much more deforestation, more environmental and ecological problems. To make the palm oil sector sustainable and profitable, it is essential to combine the efforts of palm oil players including the smallholders, plantation companies, governments, certification agencies, consumers and researchers. Only with a substantial increase of oil yield per land area and increased smallholders' wealth, as well as awareness of effects of oil palm plantation on biodiversity will they be able to devote more resources to protect the forests and environment.

\section{Acknowledgements}

This study was support by the internal fund of the Temasek Life Sciences Laboratory. We thank our lab members for collecting references on oil palm.

\section{REFERENCES}

Austin AG, Schwantes A, Gu YF, Kasibhatla PS. 2019. What causes deforestation in Indonesia. Environ. Res. Lett., 14, 024007.

Bai B, Wang L, Lee M, Zhang Y, Alfiko Y, Ye BQ, et al. 2017. Genome-wide identification of markers for selecting higher oil content in oil palm. BMC Plant Biol., 17, 93.

Bai B, Wang L, Zhang YJ, Lee M, Rahmadsyah R, Alfiko $Y$, et al. 2018. De- veloping genome-wide SNPs and constructing an ultrahigh-density linkage map in oil palm. Sci. Rep., 8, 691.

Begum H, Siwar C, Alam AF, Choy EA, Ishak S, Alam L. 2018. Enhancing sustainability amongst oil palm smallholders in Malaysia. Intern. J. Agri Resour. Gov. Ecol., 14, 62-79.

Billotte N, Jourjon M, Marseillac N, Berger A, Flori A, Asmady $\mathrm{H}$, et al. 2010. QTL detection by multi-parent linkage mapping in oil palm (Elaeis guineensis Jacq.). Theor. Appl. Genet., 120, 16731687.

Carrasco LR, Larrosa C, Milner-Gulland E, Edwards DP. 2014. A double-edged sword for tropical forests. Science, 346, 38-40.

Corley RHV, Tinker PB. 2015. The oil palm. John Wiley \& Sons.

De Pinto A, Wiebe K, Pacheco P. 2017. Commerce: Help bigger palm oil yields to save land. Nature, 544, 416.

EPOA. 2019. Palm oil production. European Palm oil Alliance, https://www. palmoilandfood.eu/en/palm-oil-production.

Fitzherbert EB, Struebig MJ, Morel A, Danielsen F, Brühl CA, Donald PF, et al. 2008. How will oil palm expansion affect biodiversity? Trends Ecol. Evol., 23, 538-545.

Gatti RC, Liang J, Velichevskaya A, Zhou M. 2019. Sustainable palm oil may not be so sustainable. Sci. Total Environ., 652, 48-51.

Goh K, Teo C, Chew P, Chiu S. 1999. Fertiliser management in oil palm-agronomic principles and field practices. Paper presented at "Fertilizer Management For Oil Palm Plantations, 20, 21.

Heffner EL, Sorrells ME, Jannink JL. 2009. Genomic selection for crop improvement. Crop Sci., 49, 1-12.

Higgins V, Richards C. 2019. Framing sustainability: Alternative standards 
schemes for sustainable palm oil and South-South trade. J. Rur. Stu., 65, 126-134.

Hirbli T. 2018. Palm Oil traceability: Blockchain meets supply chain. Massachusetts Institute of Technology.

Hutabarat S, Slingerland M, Rietberg P, Dries L. 2018. Costs and benefits of certification of independent oil palm smallholders in Indonesia. Intern. Food Agribus. Manag. Rev., 21, 681-700.

Jin J, Lee M, Bai B, Sun Y, Qu J, Alfiko Y, et al. 2016. Draft genome sequence of an elite Dura palm and whole-genome patterns of DNA variation in oil palm. DNA Res., 23, 527-533.

Kamiran N, Sarker M. 2014. Exploring the potential of high resolution remote sensing data for mapping vegetation and the age groups of oil palm plantation, IOP Conference Series: Earth and Environmental Science. IOP Publishing, pp. 012181.

Koh LP, Wilcove DS. 2008. Is oil palm agriculture really destroying tropical biodiversity? Conserv. Lett., 1, 60-64.

Koh LP, Wilcove DS. 2009. Oil palm: disinformation enables deforestation. Trends Ecol. Evol., 24, 67-68.

Koh LP, Lee TM. 2012. Sensible consumerism for environmental sustainability. Biol. Conserv., 151, 3-6.

Kwong QB, Teh CK, Ong AL, Heng HY, Lee HL, Mohamed M, et al. 2016. Development and validation of a high-density SNP genotyping array for African oil palm. Mol. Plant, 9, 1132-1141.

Kwong QB, Ong AL, Teh CK, Chew FT, Tammi M, Mayes S, et al. 2017. Genomic selection in commercial perennial crops: applicability and improvement in oil palm (Elaeis Guineensis Jacq.). Sci. Rep., 7, 2872.

Lai O-M, Tan C-P, Akoh CC. 2015. Palm oil: Production, processing, characterization, and uses. Elsevier.

Lee CT, Hashim H, Ho CS, Fan YV, Kle- mes JJ. 2017. Sustaining the low-carbon emission development in Asia and beyond: Sustainable energy, water, transportation and low-carbon emission technology. J. Clean. Prod., 146, 1-13.

Lee M, Xia JH, Zou Z, Ye J, Alfiko Y, Jin J, et al. 2015. A consensus linkage map of oil palm and a major QTL for stem height. Sci. Rep., 5, 8232.

Liaghat S, Balasundram SK. 2010. A review: The role of remote sensing in precision agriculture. Am. J. Agri. Biol. Sci., 5, 50-55.

Mancini A, Imperlini E, Nigro E, Montagnese C, Daniele A, Orrù S, et al. 2015. Biological and nutritional properties of palm oil and palmitic acid: Effects on health. Molecules, 20, 17339-17361.

McPhail K, Maimunah TF. 2012. Regulating for rights and sustainability: biofuel in Malaysia. Account. Manag. Policy J., 3, 252-261.

Meijaard E, Garcia-Ulloa J, Sheil D, Wich $\mathrm{S}$, Carlson K, Juffe-Bignoli $\mathrm{D}$, et al. 2018. Oil palm and biodiversity: A situation analysis by the IUCN Oil Palm Task Force.

Navulur S, Prasad MG. 2017. Agricultural management through wireless sensors and internet of things. Intern. J. Electr. Comp. Engr., 7, 3492.

Naylor RL, Higgins MM, Edwards RB, Falcon WP. 2019. Decentralization and the environment: Assessing smallholder oil palm development in Indonesia. Ambio, 1-14.

Ong-Abdullah M, Ordway JM, Jiang N, Ooi S-E, Kok S-Y, Sarpan N, et al. 2015. Loss of Karma transposon methylation underlies the mantled somaclonal variant of oil palm. Nature, 525, 533.

Ordway EM, Naylor RL, Nkongho RN, Lambin EF. 2019. Oil palm expansion and deforestation in Southwest Cameroon associated with proliferation of informal mills. Nature Commun., 10, 114. 
Padfield R, Hansen S, Davies ZG, Ehrensperger A, Slade E, Evers S, et al. 2019. Co-producing a research agenda for sustainable palm oil. Front. Forests Glob. Chan., 2, 13.

Paoli GD, Yaap B, Wells PL, Sileuw A. 2010. CSR, Oil Palm and the RSPO: Translating boardroom philosophy into conservation action on the ground. Trop. Conserv. Sci., 3, 438-446.

Perbet $P$, Fortin $M$, Ville $A$, Béland $M$. 2019. Near real-time deforestation detection in Malaysia and Indonesia using change vector analysis with three sensors. Int. J. Remote Sens., 40, 74397458.

PootakhamW, Jomchai N, Ruang-areerate $P$, Shearman JR, Sonthirod C, Sangsrakru D, et al. 2015. Genome-wide SNP discovery and identification of QTL associated with agronomic traits in oil palm using genotyping-by-sequencing (GBS). Genomics, 105, 288-295.

Rist L, Feintrenie L, Levang P. 2010. The livelihood impacts of oil palm: smallholders in Indonesia. Biodivers. Conserv., 19, 1009-1024.

Santosa Y, Sunkar A, Kwatrina RT. 2020. Is it True that Oil Palm Plantations are the Main Driver of Indonesia's Tropical Forest Deforestation? Internat. J. Oil Palm, 3, 1-10.

Shimizu H, Desrochers P. 2012. The health, environmental and economic benefits of palm oil. IEM's Econ. Note, Sept, 1-4.

Singh R, Tan SG, Panandam JM, Rahman RA, Ooi LC, Low E-TL, et al. 2009. Mapping quantitative trait loci (QTLs) for fatty acid composition in an interspecific cross of oil palm. BMC Plant Biol., 9, 114.

Singh R, Ong-Abdullah M, Low E-TL, Manaf MAA, Rosli R, Nookiah $R$, et al. 2013a. Oil palm genome sequence reveals divergence of interfertile species in Old and New worlds. Nature, 500,
335.

Singh R, Low E-TL, Ooi LC-L, Ong-Abdullah M, Ting N-C, Nagappan J, et al. 2013b. The oil palm SHELL gene controls oil yield and encodes a homologue of SEEDSTICK. Nature, 500, 340.

Singh R, Low E-TL, Ooi LC-L, Ong-Abdullah M, Nookiah R, Ting N-C, et al. 2014. The oil palm VIRESCENS gene controls fruit colour and encodes a R2R3MYB. Nature Commun., 5, 4106.

Soh AC, Mayes S, Roberts JA. 2018. Oil Palm Breeding: Genetics and Genomics. CRC Press, Boca Raton.

ST. 2018. (The Straits Time) Indonesia halts new oil palm plantation development https://www.straitstimes.com/asia/se-asia/indonesia-halts-new-palm-oil-plantation-development.

ST. 2019. Malaysia plans to halt all expansion of oil palm plantations, minister says. https://www.straitstimes.com/ asia/se-asia/malaysia-plans-to-halt-allexpansion-of-palm-oil-plantations-minister-says.

Teh C-K, Ong A-L, Kwong Q-B, Apparow S, Chew F-T, Mayes S, et al. 2016. Genome-wide association study identifies three key loci for high mesocarp oil content in perennial crop oil palm. Sci. Rep., 6, 19075.

Ting N-C, Jansen J, Mayes S, Massawe $F$, Sambanthamurthi R, Ooi LC-L, et al. 2014. High density SNP and SSRbased genetic maps of two independent oil palm hybrids. BMC Genomics, 15, 309.

Wayne LL, Gachotte DJ, Walsh TA. 2019. Transgenic and Genome Editing Approaches for Modifying Plant Oils, Transgenic Plants. Springer, Country pp. 367-394.

Wilman EA. 2019. Market Redirection Leakage in the Palm Oil Market. Ecol. Econ., 159, 226-234.

Woittiez LS, van Wijk MT, Slingerland M, 
van Noordwijk M, Giller KE. 2017. Yield gaps in oil palm: A quantitative review of contributing factors. Eu. J. Agron., 83, 57-77.

Yamamoto $\mathrm{Y}$, Shigetomi $\mathrm{Y}$, Ishimura $\mathrm{Y}$, Hattori M. 2019. Forest change and agricultural productivity: Evidence from Indonesia. World Devel., 114, 196-207. Zaki HHM, Rahim MARA. 2019. Palm Oil: Malaysia -EU Trade Issue, Khazanah Research Institute. 